\title{
Factor VIII Measurement
}

National Cancer Institute

\section{Source}

National Cancer Institute. Factor VIII Measurement. NCI Thesaurus. Code C81961.

The determination of the amount of factor VIII present in a sample. 